\title{
Distribution and Population Status of Bald Eagles (Haliaeetus leucocephalus) in Interior Alaska
}

\author{
ROBERT J. RITCHIE ${ }^{1}$ and SKIP AMBROSE 2
}

(Received 26 January 1995; accepted in revised form 27 November 1995)

\begin{abstract}
We summarize information available on natural history, numbers, distribution, and status of bald eagles (Haliaeetus leucocephalus) in six regions of interior Alaska: Upper Yukon, Lower Yukon, Tanana, Kuskokwim, Susitna, and Upper Copper. We identified 347 nesting territories using information from local researchers, a raptor nest atlas, unpublished raptor survey reports, and our own surveys. Nearly $85 \%$ of these territories were from the Copper, Susitna, and Tanana drainages. Extrapolating from the number of known nests and approximate survey coverage per drainage, we estimate that 525 to 725 pairs of bald eagles nest in interior Alaska. Observations also suggest that this population has increased substantially since the middle of this century and that numbers in some areas continue to increase. Reasons for these increases may include (1) improving health of individuals in this population; (2) reduced persecution in Alaska and in wintering areas outside the state; (3) immigration into interior Alaska from rebounding or expanding populations elsewhere; and (4) changing environmental conditions (e.g., warmer temperatures). Banding and migration data suggest that part of the population that nests north of the Alaska Range may winter in areas different from those used by populations that nest south of the Alaska Range. No environmental contaminants measured in eggs occurred at concentrations known to result in sublethal or lethal effects, and most organochlorine pesticide and mercury concentrations were an order of magnitude lower than concentrations in bald eagle eggs elsewhere in the United States.
\end{abstract}

Key words: bald eagles, Haliaeetus leucocephalus, Alaska, breeding ecology, migration, contaminants

RÉSUMÉ. On fait la synthèse de l'information disponible sur l'histoire naturelle, l'inventaire, la distribution et le statut du pygargue à tête blanche (Haliaeetus leucocephalus) dans six régions de l'intérieur de l'Alaska: le Haut-Yukon, le Bas-Yukon, la Tanana, la Kuskokwim, la Copper supérieure et la Susitna. En utilisant l'information obtenue auprès de chercheurs locaux, un atlas sur les nids de rapaces, des rapports d'enquêtes non publiés sur les rapaces et nos propres enquêtes, on a identifié 347 territoires de nidification. Près de $85 \mathrm{p}$. cent de ces territoires se trouvaient dans les bassins de la Copper, de la Susitna et de la Tanana. En extrapolant à partir du nombre de nids connus et de la superficie approximative d'enquête pour chaque bassin hydrographique, on pense que de 525 à 725 paires de pygargues à tête blanche nichent dans l'intérieur de l'Alaska. Des observations suggèrent également que cette population a augmenté considérablement depuis le milieu du siècle et que les nombres continuent d'augmenter dans certaines régions. Plusieurs raisons expliquent ces augmentations, parmi lesquelles 1) une amélioration de la santé des individus dans cette population; 2) une persécution moindre en Alaska et dans les gîtes d'hivernage en dehors de l'État; 3) une immigration vers l'intérieur de l'Alaska de populations en train de reprendre le dessus ou de se développer; et 4) une évolution des conditions environnementales (réchauffement de la température p. ex.). Les données de baguage et de migration suggèrent qu' une partie de la population nichant au nord de la chaîne de l'Alaska hiverne peut-être dans d'autres régions que celles utilisées par les populations nichant au sud de cette chaîne. Aucun contaminant environnemental mesuré dans les oeufs n'était présent à une concentration connue pour des effets sublétaux ou létaux, et la plupart des concentrations de pesticides organochlorés et de mercure étaient un ordre de grandeur plus basses que les concentrations présentes dans les oeufs du pygargue à tête blanche ailleurs aux États-Unis.

Mots clés: pygargue à tête blanche, Haliaeetus leucocephalus, Alaska, écologie de la nidification, migration, contaminants

Traduit pour la revue Arctic par Nésida Loyer.

\section{INTRODUCTION}

Bald eagles (Haliaeetus leucocephalus) in Alaska are most abundant in coastal areas, from southeastern Alaska north and west through the Bristol Bay region. Regular surveys in these coastal areas indicate that this regional population exceeds 30000 (Schempf, 1989). The population in Alaska's interior, however, is relatively small. With the exception of a few populations near a few large rivers, bald eagles in interior Alaska are dispersed in summer and are forced by ice and a lack of prey to leave their breeding area for 5-6 months in winter each year.

${ }^{1}$ ABR, Inc., P.O. Box 80410, Fairbanks, Alaska 99708, U.S.A.

${ }^{2}$ U.S. Fish and Wildlife Service, 1412 Airport Way, Fairbanks, Alaska 99701, U.S.A.

(C) The Arctic Institute of North America 
Much of interior Alaska has not been surveyed adequately to determine more than the relative abundance of raptors. In addition, much of the information on breeding distribution of raptors occurs only in unpublished files or on maps maintained by a variety of investigators. In this paper, we synthesize the information in these diverse data sources to present current knowledge of the distribution, abundance, and status of bald eagles in interior Alaska. Furthermore, we summarize information from our own surveys, primarily in east-central Alaska. We also suggest some physical and biological factors that may be responsible for this trend.

\section{STUDY AREA}

Interior Alaska is described broadly as an area influenced by a continental climate and containing a mix of broadleaf and conifer vegetation communities, often called the boreal forest. Nearly the entire Yukon and Kuskokwim river drainages are included. We have followed Kessel and Gibson's (1978) boundaries for a Central Region (approximately $700000 \mathrm{~km}^{2}$ ), which includes the drainages of the upper Copper and Susitna Rivers. The crest of the Brooks Range forms the northern boundary of this region and portions of the central Alaska Range, Chugach Mountains, and Wrangell Mountains comprise the southern boundary (Wahrhaftig, 1965). For the purposes of our discussion, the region has been divided into six major areas based on the major drainage in each area (Fig. 1). Areas of drainages were calculated by digitizing each region from a map of Alaska (1:2 000 000); descriptions are from Wahrhaftig (1965).

1. UPPER YUKON $\left(\sim 180000 \mathrm{~km}^{2}\right)$ : Yukon River from the Alaska-Canada border to approximately Rampart; includes the Porcupine River and its tributaries, Charley, Kandik, Nation, and Fortymile Rivers, and Birch and Beaver Creeks. Major physiographic provinces include the Porcupine Plateau, Yukon-Tanana Uplands, and the Yukon Flats;

2. LOWER YUKON $\left(\sim 190000 \mathrm{~km}^{2}\right)$ : Yukon River west of Rampart to approximately Holy Cross; includes the Koyukuk River and extensive wetlands associated with the Nowitna and Innoko Rivers;

3. TANANA $\left(\sim 118000 \mathrm{~km}^{2}\right)$ : Tanana River, including the Chisana, Nabesna, Delta, and Kantishna Rivers and other tributaries; includes basins of the Northway Tanacross Lowlands and other extensive wetlands associated with the Tanana River;

4. KUSKOKWIM $\left(\sim 95000 \mathrm{~km}^{2}\right)$ : Kuskokwim River drainage from its headwaters west to Aniak; includes Holitna and Hoholitna Rivers and other major tributaries of the Kuskokwim within the western half of the TananaKuskokwim Lowlands;
5. SUSITNA ( $\left.60000 \mathrm{~km}^{2}\right)$ : Susitna River from its headwaters to Cook Inlet; includes the Skwentna, Talkeetna, and Matanuska Rivers; and

6. UPPER COPPER $\left(\sim 50000 \mathrm{~km}^{2}\right)$ : Copper River from its headwaters to Chitina; includes the Chitina, Gakona, and Gulkana Rivers and wetlands in the Gulkana Upland and portions of the Copper River Lowland.

\section{METHODS}

We synthesized all available information on occupancy of nesting territories, breeding ecology, and migration for bald eagles in interior Alaska. A nesting territory is defined as a nest or series of nests near to one another (within $0.5 \mathrm{~km}$ ) with a recent history (within 20 years) of occupancy by a pair. Breeding ecology includes information on nest sites, breeding chronology, food habits, and productivity. Migration data were obtained from band recovery information supplied by the U.S. National Biological Service, Bird Banding Laboratory, Laurel, Maryland. Contaminant analyses of eggs collected at nests on the Tanana River were provided by a U.S. Fish and Wildlife Service contract laboratory.

Our primary data sources for population estimates were unpublished raptor surveys, our own surveys, an atlas of raptor nest sites developed for the U.S. Fish and Wildlife Service in 1981, and personal communications with biologists familiar with each region. Because these data were gathered using various survey methods, often with different objectives, and conducted over a wide range of dates by different observers, the accuracy of those estimates-and, consequently, the value of our extrapolations from those estimates-varies among subregions. Most of the surveys were conducted between the mid-1970s and the early 1990s. Survey methods included using fixed-wing aircraft, helicopters, and boats to make observations. Population estimates were derived from the total number of known pairs in a given region relative to the approximate portion of the region surveyed.

\section{RESULTS}

\section{Breeding Ecology}

Bald eagles in interior Alaska are primarily summer residents, arriving as early as late March and departing by freezeup in mid-to-late October. Nests are usually located in a dominant tree in a stand close to shorelines. Most nests on the Tanana River were within $100 \mathrm{~m}$ of a shoreline (Ritchie, 1982). Balsam poplar (Populus balsamifera) was used most frequently along the Tanana (Ritchie, 1982) and Susitna (Parker, 1988) Rivers, but white spruce (Picea glauca) was also used regularly, especially at off-river sites or at higher elevations, where balsam poplars are less common. Groundnesting, which is common on the Alaskan coast (Hehnke, 


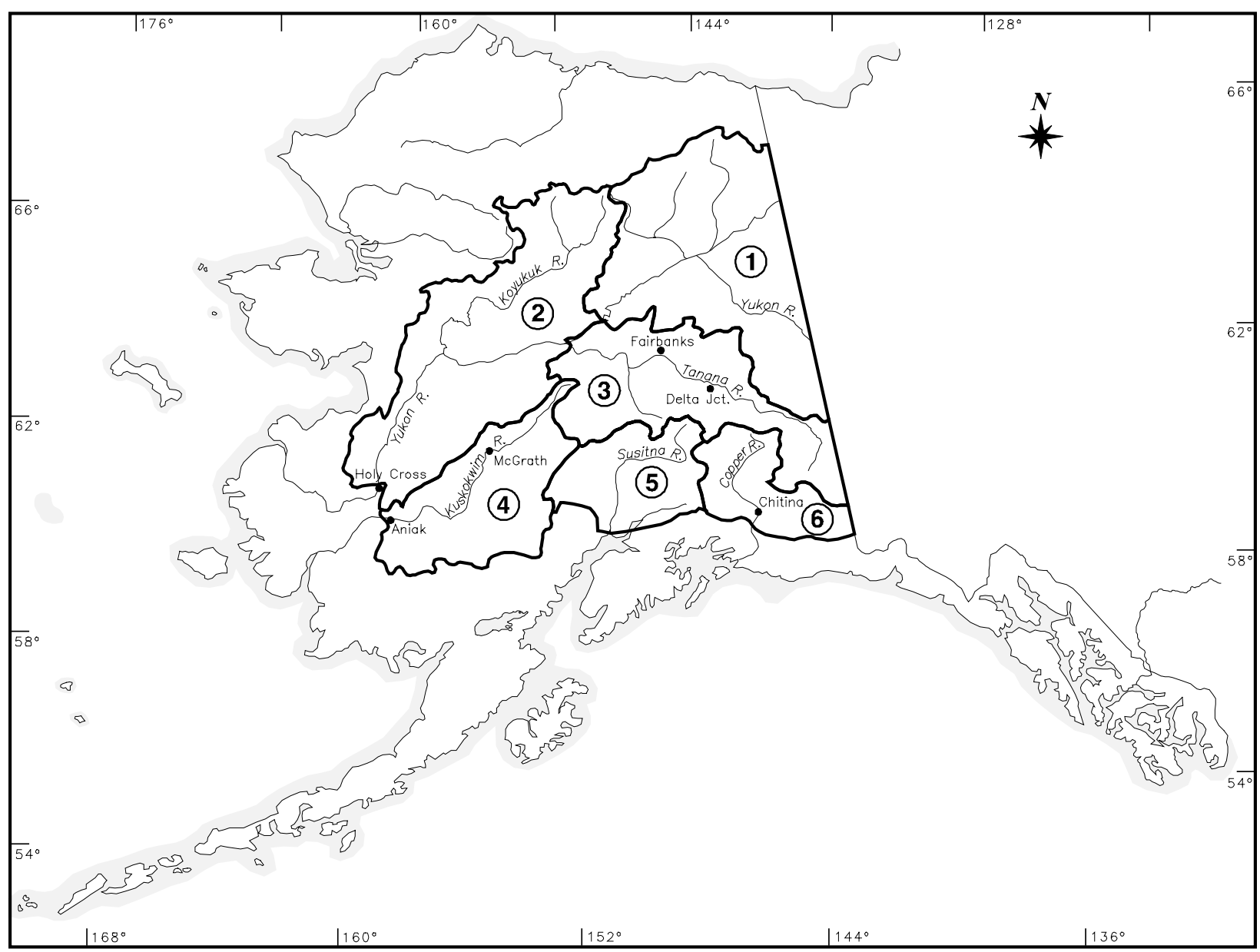

FIG. 1. Six major drainage regions in interior Alaska: 1) Upper Yukon; 2) Lower Yukon; 3) Tanana; 4) Kuskokwim; 5) Susitna; and 6) Upper Copper.

1973; Sherrod et al., 1976), is rare in the boreal forest (Bromley and Trauger, 1974). However, at least two ground nests have been identified in interior Alaska, on the upper Susitna River (Kessel et al., 1982) and on the upper Delta River (Wilbor, 1989).

Chronology data are lacking for most regions in interior Alaska, but results of three years of bird migration studies in the upper Tanana River Basin showed peak arrival of bald eagles occurs in late April and peak departure after midSeptember (Cooper et al., 1991). Along the Tanana River, chronology appears to be influenced primarily by prey availability. Birds, especially waterfowl, are important in the diet of interior bald eagles, accounting for $43 \%$ of prey items in nests along the Tanana River (Ritchie, 1982). Use of avian prey may be particularly prevalent in spring, when most waterbodies are still frozen. Salmon appear to be more important prey than avian species in late summer and fall.

Reestablishment of territories and nest reconstruction begins in late April. Onset of incubation probably peaks by the second week of May, although hatching in the first week of June near Delta Junction indicates that overwintering birds or early arrivals nest earlier (Ritchie, 1982). Most young fledge by late August. On the upper Tanana River, between 1978 and 1990, 79.5\% of breeding pairs checked for productivity $(\mathrm{n}=151)$ produced young to near fledging age, and mean productivity was 1.57 young per successful pair (range 1.0-2.33) (Ritchie, 1982; Ambrose, unpubl. data). Grier (1982) and Gerrard et al. (1983) reported similar rates for boreal populations in Canada.

\section{Migration and Wintering}

Information on migration and wintering areas is limited. Approximately 100 bald eagle nestlings have been banded since 1984 along interior rivers, primarily the upper Yukon, upper Tanana, and Copper Rivers, and we are aware of five relevant recoveries. Three of these records were winter recoveries inland in western North America: an eagle banded on the Kandik River, a tributary of the upper Yukon River, was recovered in south-central British Columbia; an eagle banded on the upper Tanana River was recovered in northcentral Washington; and an eagle banded on the upper Tanana River was recovered in northwest Wyoming. The other two recoveries were from eagles banded along the upper Tanana River and Gulkana River; both were recovered two years later, during the breeding season, in the vicinity of the banding location.

In addition to these recoveries, two other band returns provide insight on the movements of interior bald eagles. An eagle banded in late fall in Glacier National Park, Montana, 
was recovered the following summer near McGrath, Alaska (unpubl. banding records, Bird Banding Laboratory, Laurel, Maryland), and a subadult bald eagle banded in Saskatchewan was recovered near Juneau, Alaska (Gerrard et al., 1978). While four of these recoveries suggest bald eagles from interior Alaska winter in continental regions of western North America, the Saskatchewan eagle recovery suggests some exchange between coastal and interior areas. Observations along the Copper River near Chitina also suggest movements of bald eagles between interior Alaska (Nelchina Basin) and the coast (Cooper et al., 1991). To date, however, there have been no reported recoveries of interior bald eagles in coastal areas of south-central and southeastern Alaska, nor have there been any reported recoveries of coastal bald eagles in interior Alaska.

Bald eagles have been observed regularly on the Tanana River near Delta Junction during midwinter (Ritchie and Ambrose, 1987). These eagles were most frequently observed near extensive open water, associated with wintering waterfowl and late salmon runs. Open water in other drainages may also provide limited foraging possibilities for overwintering eagles.

\section{Environmental Contaminants}

It is difficult to assess the influence of pesticides on bald eagles in interior Alaska, because no historical data are available. A comparison of recent data (1990-91, Table 1) with data from populations in the continental United States, however, shows that levels of contaminants in bald eagle eggs from Alaska are currently much lower than levels of contaminants found in southern populations. For seven eggs collected in Alaska in 1990 and 1991, DDE averaged 0.573 ppm (wet weight), DDD averaged $0.063 \mathrm{ppm}$ (wet weight), and DDT was below detection limits $(0.009 \mathrm{ppm})$ in five of seven eggs (two eggs averaged $0.012 \mathrm{ppm}$, wet weight). Other contaminants measured in these eggs were often below detection limits. No eggshell thinning was detected in the seven eggs analyzed. None of the contaminants occurred at concentrations known to result in sublethal or lethal effects, and most organochlorine pesticide and mercury concentrations were an order of magnitude lower than concentrations in bald eagle eggs elsewhere in the United States (Anthony et al., 1993; Conzelmann and Rabot, 1994).

\section{Regional Distribution and Abundance}

Approximately 350 nesting territories were identified in interior Alaska from all sources prior to 1991. The distribution and relative abundance of bald eagles in each subregion vary (Fig. 2; Table 2). Nearly $85 \%$ of known nesting pairs occurred in the Susitna, upper Copper, and Tanana drainages; these three areas also have had the most survey coverage for bald eagles.

Upper Yukon: Raptor surveys on the upper Yukon and its tributaries suggest that bald eagles are uncommon and dispersed. Most nest records are from drainages south of the
TABLE 1. Concentrations of environmental contaminants in bald eagle eggs from the Tanana River, Alaska, 1990-91.

\begin{tabular}{lccc}
\hline \hline Contaminant & No. of Eggs & $\begin{array}{c}\text { Mean } \\
(\mathrm{ppm})\end{array}$ & $\begin{array}{c}\text { Range } \\
(\mathrm{ppm})\end{array}$ \\
\hline p,p' DDE & 7 & 0.573 & $0.333-0.953$ \\
p,p' DDD & 6 & 0.063 & $0.022-0.166$ \\
p,p' DDT & 2 & 0.012 & \\
“" & 5 & $<0.009^{1}$ & \\
Dieldrin & 7 & 0.028 & $0.007-0.089$ \\
Oxychlordane & 7 & 0.019 & $0.007-0.033$ \\
cis-Chlordane & 6 & 0.027 & $0.014-0.045$ \\
cis-Nonachlor & 6 & 0.023 & $0.014-0.038$ \\
trans-Nonachlor & 7 & 0.084 & $0.012-0.043$ \\
HCB & 7 & 0.011 & $0.003-0.018$ \\
Heptachlor Epoxide & 6 & 0.019 & $0.007-0.034$ \\
Mirex & 6 & 0.007 & $0.004-0.009$ \\
Total PCBs & 7 & 1.258 & $0.765-2.150$ \\
Mercury & 6 & 0.120 & $0.073-0.191$ \\
trans-Chlordane & 7 & $<0.009^{1}$ & \\
alpha-BHC & 7 & $<0.009^{1}$ & \\
gamma-BHC & 7 & $<0.009^{1}$ & \\
beta-BHC & 7 & $<0.009^{1}$ & \\
delta-BHC & 7 & $<0.009^{1}$ & \\
Endrin & 7 & $<0.009^{1}$ & \\
Total Toxaphene & 7 & $<0.167^{1}$ & \\
Thickness (mm) & 7 & 0.626 & \\
Percent Change & $+2 \%$ & & \\
\hline \hline
\end{tabular}

${ }^{1}$ Minimum detection limit.

${ }^{2}$ Mean eggshell thickness of bald eagle eggs prior to 1946 was $0.609 \mathrm{~mm}$ (Anthony et al., 1993).

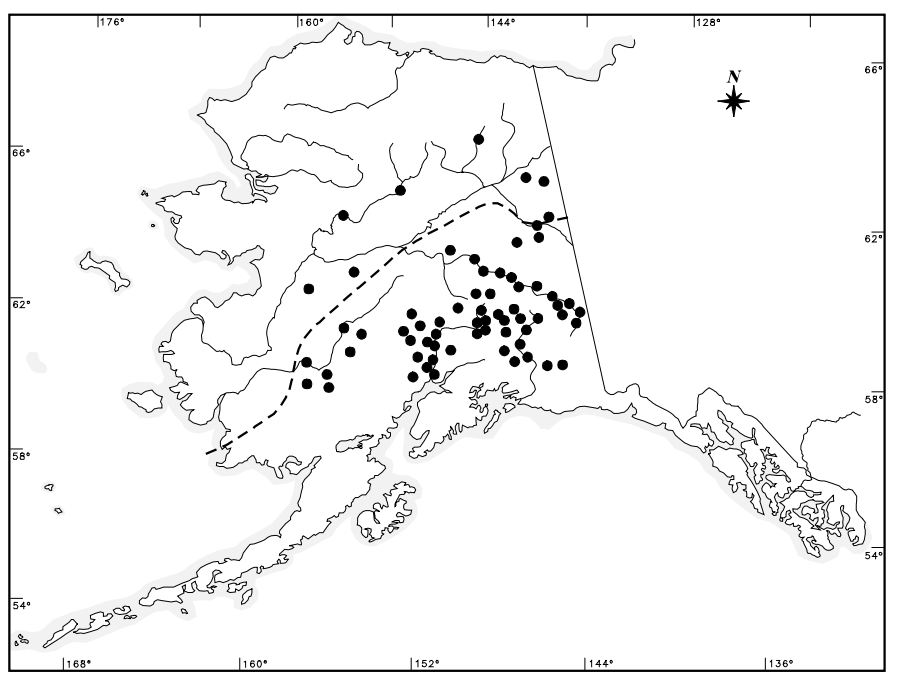

FIG. 2. General distribution of bald eagles in interior Alaska (single dot $=$ 1-5 nest territories) and 30 April ice-breakup line (Source: National Weather Service, River Forecast Center, Anchorage, Alaska).

Porcupine River, including the Black and Charley Rivers (Ritchie, 1984; M. Britten, pers. comm. 1989). Nests occasionally have been located in drainages on the south side of the Brooks Range (e.g., East Fork Chandalar; Roseneau, 1974) and along the Kandik, Nation, Birch, and Fortymile Rivers (Kuropat, 1986; T. Swem, pers. comm. 1989). The Yukon Flats area, a major wetland, has not been surveyed for bald eagles, but nests have been recorded there during waterfowl surveys (J. Hodges, pers. comm. 1990). Existing data 
suggest approximately 35 nesting pairs in the areas that have been surveyed, and on the basis of approximate coverage and potential habitat, we estimate $75-100$ pairs nest in the entire upper Yukon drainage.

Lower Yukon: With the exception of American peregrine falcon (Falco peregrinus anatum) surveys along the Yukon River and on the upper Koyukuk River, no intensive raptor surveys have been undertaken in this area. Bald eagles are rare breeders along the lower Yukon River (Springer et al., 1979; Mindell and Craighead, 1981), but approximately 20 different nesting territories have been located along the Innoko, Koyukuk and Nowitna Rivers (T. Osborne, pers. comm. 1990; P. Feiger and M. Bertram, pers. comm. 1990). We estimate that 50-75 pairs nest in this region.

Tanana: Bald eagle surveys have occurred regularly in the Tanana River basin (Roseneau and Bente, 1979; Ritchie, 1982; Cooper et al., 1991; Timm et al., 1993; R. Ambrose, unpubl. notes). Bald eagles are a common breeding bird in this region, and there are at least 70 pairs along the upper Tanana (east of Fairbanks) and Chisana Rivers and in the extensive wetlands near Tetlin Lake. In addition, occasional nests have been identified along other Tanana River tributaries, including the Salcha, Chatanika, Nabesna, Delta, and Nenana Rivers, along the Tanana River west of Fairbanks, and on major lakes in associated lowlands. We estimate that 75-100 pairs of bald eagles nest along the Tanana River and its major tributaries.

Kuskokwim: Raptor surveys have been conducted west of McGrath on the Kuskokwim River and some of its tributaries (Ritchie and Ambrose, 1976; Mindell, 1983). In addition, several other bald eagle nests scattered throughout the area have been reported (P. Shepherd, pers. comm. 1990; J. Whitman, pers. comm. 1990). However, with the exception of the Holitna and Hoholitna Rivers (approximately 15 pairs; Alaska Department of Fish and Game, unpubl. maps, 1976), bald eagles apparently are not common in the Kuskokwim drainage. Only three nests have been located between McGrath and Aniak, and bald eagles were rare along 18 rivers in this area and immediately to the west (Mindell, 1983). White and Boyce (1978) also surveyed rivers in the area and rarely located nests of this species. Most tributaries have not been surveyed intensively, but almost all major tributaries have records of scattered nests (J. Whitman, pers. comm. 1990). We can account for a minimum of 32 different nesting territories in the region and estimate $50-75$ pairs nest in the Kuskokwim drainage.

Upper Copper: Numerous raptor surveys have occurred in the upper Copper River basin (Haugh and Halperin, 1976; Amaral, 1988; Wilbor, 1989; B. Stiedl, pers. comm. 1990; Cooper et al., 1991). Bald eagles are common breeders in all major drainages and in the extensive wetlands of the Nelchina Basin. At least 110 nesting pairs have been located, with concentrations on the Gulkana, mid-Copper, and upper Gakona Rivers. In addition, the large number of nesting sites in upland wetlands in this region makes extrapolations difficult. We estimate that $125-175$ pairs nest in the upper Copper River region.
Susitna: The Susitna Hydroelectric Project and proposed timber sales resulted in intensive bald eagle investigations in this region (White, 1974; White and Cade, 1975; Kessel et al., 1982; Parker, 1988). Bald eagles are common, and nests have been found along the Susitna, Talkeetna, Yentna, Skwentna, Chulitna, Beluga, and Kahiltna Rivers. Nests appear to be uniformly distributed. Parker (1988) estimated 125 pairs for the entire basin. Additional nests occur on the upper Susitna River (Kessel et al., 1982) and probably in other drainages and wetlands in the region. We estimate that 150-200 pairs nest in the Susitna basin.

On the basis of over 300 nest records and an assessment of available habitats, we conclude that bald eagles in interior Alaska nest most commonly in the upper Tanana, Copper, and Susitna drainages; less commonly in the Kuskokwim and upper Yukon drainages; and uncommonly in the lower Yukon drainage. Based on the above regional information, we estimate that 525-725 bald eagle pairs nest annually in interior Alaska. If 75 to $80 \%$ of these pairs are successful in raising 1.5 young per pair, the total fall population may exceed 2000 bald eagles, excluding nonterritorial adults and subadults, for whom data are not available. Since less than $25 \%$ of the wetlands in interior Alaska have been surveyed intensively for raptors, and since the density of nesting bald eagles in areas surveyed varied substantially, it is difficult to generate a more precise estimate for the entire area. In addition, variable survey coverage may account for some of the regional differences in our estimates.

\section{DISCUSSION}

The distribution and abundance of bald eagles in interior Alaska is likely influenced by several biological and physical factors. Bald eagles are most common in interior regions that are adjacent to coastal areas where bald eagles are abundant. Regions closest to tidewater are influenced to some degree by the ameliorations of maritime weather conditions; thus, bald eagles may be more common in these regions because of milder weather and more accessible prey. Conversely, bald eagle distribution in regions north of the Alaska Range appear to be limited by more severe continental climatological conditions, which result in a shorter breeding season. Bald eagles appear to be uncommon north of a 30 April ice-breakup line (Fig. 2), beyond which one could expect an even more limited nesting season. Mean temperatures in April and density of breeding eagles were found to be correlated for a population of bald eagles in Saskatchewan (Leighton et al., 1979).

Areas with the densest populations of bald eagles north of the Alaska Range also may have more diverse and seasonally vulnerable prey bases than the majority of wetlands in interior Alaska. For instance, bald eagles are fairly common on the Tanana River, the Black River in the Porcupine drainage (upper Yukon region), and the Holitna River in the Kuskokwim River basin. Because of similar hydrologic characteristics, these locations or their tributaries have late spawning runs of 
TABLE 2. Known and estimated number of territorial pairs of bald eagles in six subregions of interior Alaska.

\begin{tabular}{lccc}
\hline \hline Region & Area Surveyed $(\%)^{1}$ & Known Pairs & Estimated Pairs ${ }^{2}$ \\
\hline Upper Yukon $^{3}$ & $35-50$ & 35 & $75-100$ \\
Lower Yukon $^{4}$ & $15-25$ & 20 & $50-75$ \\
Tanana $^{5}$ & $\sim 75$ & 70 & $75-100$ \\
Kuskokwim $^{6}$ & $40-50$ & 32 & $50-75$ \\
Upper Copper $^{7}$ & $\sim 75$ & 110 & $125-175$ \\
Susitna $^{8}$ & $\sim 75$ & 80 & $150-200$ \\
Totals & & 347 & $525-725$ \\
\hline \hline
\end{tabular}

${ }^{1}$ Estimate of area with some history of surveys.

${ }^{2}$ Estimates were derived from total known pairs and approximate area covered; the range reflects discussions with observers in each area.

3 Roseneau, 1974; Haugh and Halperin, 1976; Ritchie, 1984; Kuropat, 1986; R. Ambrose, unpubl. data; T. Swem, M. Britten and C. McIntyre, pers. comm. 1989.

${ }^{4}$ Springer et al., 1979; Mindell and Craighead, 1981; T. Osborne, P. Feiger, M. Bertram, pers. comm. 1990.

${ }^{5}$ Roseneau and Bente, 1979; Amaral, 1982; Ritchie, 1982; Timm et al., 1993.

${ }^{6}$ Mindell, 1983; P. Shepherd, J. Whitman, pers. comm. 1990.

${ }^{7}$ Haugh and Halperin, 1976; Wilbor, 1989; Cooper et al., 1991; B. Stiedl, K. Kozie, pers. comm. 1990.

${ }^{8}$ White, 1974; White and Cade, 1975; Kessel et al., 1982; Parker, 1988; R. King, pers. comm. 1990.

sheefish (Stenodus leucichthys) and salmon, and early openings in ice cover in spring (K. Alt, pers. comm. 1990). Additionally, clear water in these locations makes prey fish available to eagles and also attracts overwintering waterfowl, which are occasionally taken by bald eagles.

Although bald eagles currently are common breeders in interior Alaska, historical accounts of nesting in the region are limited, suggesting that eagles either were overlooked on early biological surveys or were much less common than today. Gabrielson and Lincoln (1959) described the species as occurring along many interior rivers and common on some of them. Although their report lacked definite nesting records, they suspected that breeding occurred in interior Alaska. Their uncertainty was probably due to the lack of references to bald eagles in species accounts by early naturalists. For example, naturalists who traveled through Alaska from the turn of the century through the 1930s noted the bald eagle as uncommon or did not list it (Yukon: Dall and Bannister, 1869; Osgood and Bishop, 1900; Blackwelder, 1919; Kuskokwim: Hinckley, 1900; Dice, 1920a; Chitina: Laing and Taverner, 1929; Tanana and Koyukuk: Murie, 1921 -22). At the same time, however, the nests of other treenesting raptors, such as the osprey (Pandion haliaetus) and red-tailed hawk (Buteo jamaicensis) often were recorded (e.g., Dice, 1920b; Murie, 1921-22), suggesting that bald eagles may be more common breeders today than they were prior to 1930. Indeed, bald eagles did not figure prominently in ornithological literature for interior Alaska until the 1970s, when their listing under the Endangered Species Act in parts of their range gave an impetus for conducting raptor surveys during environmental assessments of proposed industrial developments. Was this apparent change in population numbers in Alaska simply a result of increased awareness, or was it related to actual population changes? We think both factors are involved, but suggest that a real population increase is the main reason for the higher numbers of bald eagles observed in interior Alaska. We believe the four factors discussed below contributed to this increase.

First, the wide use of pesticides severely affected many breeding populations of bald eagles in the contiguous United States (Stalmaster, 1987). Although historical pesticide data are not available for interior Alaskan eagles, these birds appear to winter to the south, where they could have picked up enough contamination to reduce nesting success. Recent analysis of eggs from bald eagles in interior Alaska, however, showed that no contaminant measured occurred at levels sufficient to influence reproduction. The restrictions placed on the use of organochlorine pesticides in 1973 have almost certainly contributed to higher rates of breeding success in this population, and this has contributed to the increase in the population.

Second, persecution of bald eagles in Alaska is well documented and has influenced their abundance in coastal Alaska. The Bounty Acts of 1917 and 1949 accounted for a minimum of 128273 eagles killed between 1917 and 1952 (Robards and King, 1966). Hansen and Hodges (1985) suggested that the population in southeast Alaska was substantially reduced during the bounty period and has rebounded since that time. Although most bounties were paid in southeast and southwest Alaska (Robards and King, 1966), the Bounty Acts' influence on nesting bald eagles probably extended into interior Alaska. In addition, because the few banding records and migration data available suggest that interior birds may not interchange regularly with coastal populations, other forms of persecution of interior, noncoastal populations in Alaska may have played an equally important part in the noticeable absence of bald eagles during the exploration era in Alaska. From the 1930s through the 1970s, sheep ranchers made systematic efforts to exterminate eagles from western states (Stalmaster, 1987) in which bald eagles from interior Alaska regularly wintered. Even in the early exploration era in Alaska, shooting was probably common. Osgood and Bishop (1900:74) described trying to collect the female at a nest and, although she was too high in the tree "for our No. 4 shot," a passerby shot the male with a rifle! Some negative effects on bald eagles resulted from early settlement in Alaska and the Bounty Acts. These adverse effects generally do not occur today.

Third (and no doubt related to the first two reasons), the bald eagle has been increasing throughout its range. The U.S. Fish and Wildlife Service recently proposed that the status of bald eagles in the contiguous United States be changed from endangered to threatened. As the productivity of populations to the south improved, the number of birds available to expand into other areas increased. Our small number of band 


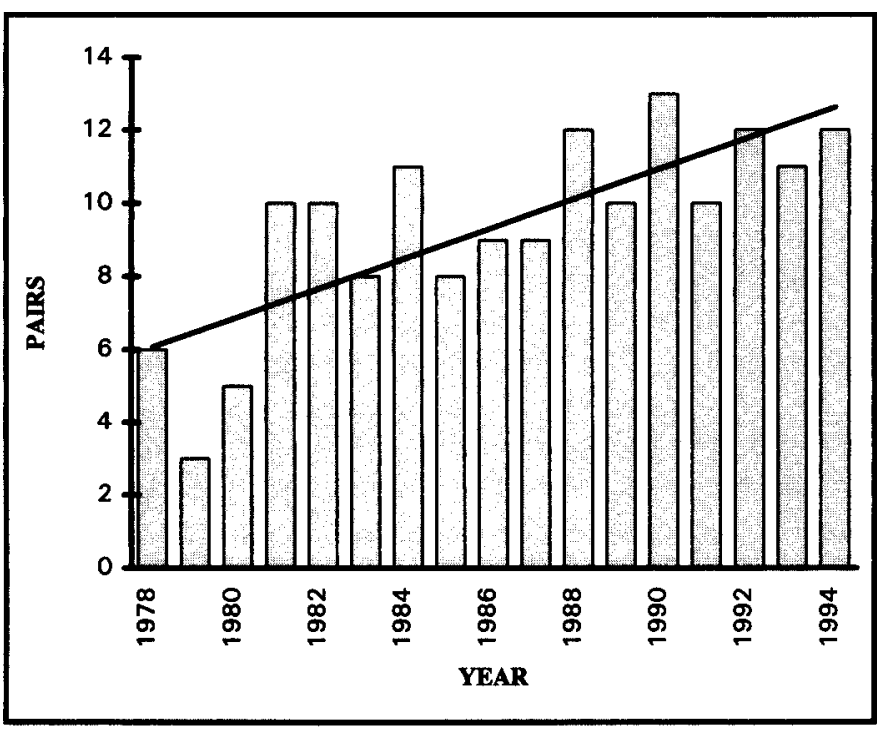

FIG. 3. Number of bald eagle pairs along the middle Tanana River, Alaska, $1978-94$.

returns suggests that bald eagles from interior Alaska may associate more with bald eagles from the western United States than with those from coastal areas in Alaska.

Finally, Swenson (1983) argued that expansion of the breeding range of bald eagles in Canada, pronounced in the past 40 years, is due to a warming trend. Other well-studied raptors, the Arctic peregrine falcon ( $F$. p. tundrius) and American peregrine falcon, are now more numerous than in the early 1950s in northern parts of their ranges (Ambrose et al., 1988a). Although their recovery is due in great part to the decline in the use of pesticides (Ambrose et al., 1988b), their rate and degree of recovery may also have been influenced by similar regional climatic changes.

Bald eagles may still be increasing in some portions of their interior range. For instance, the number of pairs on a section of the Tanana River between Tok and Delta has increased from 6 pairs in 1978 to 12 pairs in $1994\left(r^{2}=0.59\right.$, $p=0.0003$ ) (Fig. 3). Although improved survey coverage in other regions may account for some increases in numbers, survey effort on this section of the Tanana River has been consistent from 1978 to the present, and the increase in the number of pairs and new nests identified was not a result of increased survey effort (Ambrose and Ritchie, unpubl. data). This small sample and variations among years may simply represent natural variations in the population; however, combined with probable changes in previous decades, they support a hypothesis that bald eagles continue to increase in portions of their interior range.

In summary, historical records and results from intensive monitoring on the Tanana River indicate an increasing population, at least during the past twenty years. This may be due to a number of physical and biological factors, including improving health of individuals in this population, reduced persecution in Alaska and in wintering areas, immigration into this area from rebounding or expanding populations elsewhere, and changing environmental conditions (e.g., warmer temperatures). Local interior populations north of the Alaska Range may also be somewhat isolated from those in maritime-influenced regions south of the Alaska Range because of different migration corridors and wintering areas.

To refine our picture of the status of the region's population of bald eagles and to determine more adequately whether distinct local populations do exist, annual surveys need to continue on the Tanana, Susitna, and Copper Rivers, at a minimum. Regular monitoring should also be initiated in other representative drainages in each region to improve our understanding of bald eagles in interior Alaska.

\section{ACKNOWLEDGEMENTS}

We thank the many researchers who provided us with information, including M. Bertram, T. Doyle, P. Feiger, J. Hodges, T. Swem, H. Timm, and S. Wilbor, U.S. Fish and Wildlife Service; K. Alt, P. Bente, T. Osborne, P. Shepherd, J. Whitman, and J. Wright, Alaska Department of Fish and Game; B. Stiedl, Oregon State University; and M. Britten, P. Knuckles, K. Kozie, and C. McIntyre, National Park Service. D. Best and E. Synder-Conn, U.S. Fish and Wildlife Service, provided pesticide analysis and commented on bald eagle eggs from the Tanana River. B. Day, S. Murphy (ABR), and J. Fadely (U.S. Fish and Wildlife Service) provided critical review of this paper and suggested numerous improvements. Mike Smith and Allison Zusi-Cobb (ABR) worked on figures, and T. Davis (ABR) typed the manuscript.

\section{REFERENCES}

AMARAL, M.J. 1982. Peregrine falcon survey of the lower Tanana River, Fairbanks to Nenana, Alaska, 1982. Unpubl. report. Anchorage, Alaska: U.S. Fish and Wildlife Service. 6 p. Available at the U.S. Fish and Wildlife Service Library, 1011 E. Tudor Road, Anchorage, Alaska 99503, U.S.A.

1988. A survey for nesting birds of prey along the Copper River, Alaska, 1987-1988. Unpubl. report. Anchorage, Alaska: U.S. Fish and Wildlife Service, Ecological Services. 16 p. Available at the U.S. Fish and Wildlife Service Library, 1011 E. Tudor Road, Anchorage, Alaska 99503, U.S.A.

AMBROSE, R.E., RITCHIE, R.J., WHITE, C.M., SCHEMPF, P.F., SWEM, T., and DITTRICK, R. 1988a. Changes in the status of peregrine falcon populations in Alaska. In: Cade, T.J., Enderson, J.H., Thelander, C.G., and White, C.M., eds. Peregrine falcon populations, their management and recovery. Boise, Idaho: The Peregrine Fund. 73-82.

AMBROSE, R.E., HENNY, C.J., HUNTER, R.E., and CRAWFORD, J.A. 1988b. Organochlorines in Alaskan peregrine falcon eggs and their current impact on productivity. In: Cade, T.J., Enderson, J.H., Thelander, C.G., and White, C.M., eds. Peregrine falcon populations, their management and recovery. Boise, Idaho: The Peregrine Fund. 385-394.

ANTHONY, R.G., GARRETT, M.G., and SCHULER, C.A. 1993. Environmental contaminants in bald eagles in the Columbia River estuary. Journal of Wildlife Management 57:10-19. 
BLACKWELDER, E. 1919. Notes on the summer birds of the upper Yukon region, Alaska. Auk 36:657-664.

BROMLEY, R.G., and TRAUGER, D.L. 1974. Ground nesting of bald eagles near Yellowknife, Northwest Territories. Canadian Field-Naturalist 88:73-75.

CONZELMANN, P.J., and RABOT, T. 1994. Metals, organochlorine pesticides, and polychlorinated biphenyls in bald eagles of coastal Louisiana. Report LFO-EC-94-01. Lafayette, Louisiana: U.S. Fish and Wildlife Service.

COOPER, B.A., RITCHIE, R.J., ANDERSON, B.A., and BYRNE, L.C. 1991. Alaska Over-The-Horizon-Backscatter Radar System: A synthesis of the Avian Research Program 1987-1990. Unpubl. report prepared for the Arctic Environmental Information and Data Center, Anchorage, and the Department of the Air Force, Hanscom Air Force Base, Massachusetts. Prepared by and available at ABR, Inc., P.O. Box 80410, Fairbanks, Alaska 99708, U.S.A. 309 p.

DALL, W.H., and BANNISTER, H.M. 1869. List of the birds of Alaska, with biographical notes. Transactions of the Chicago Academy of Science 1, Part 2:267-310.

DICE, L.R. 1920a. Notes on some birds of interior Alaska. Condor 22:176-184.

1920b. The land vertebrate associations of interior Alaska. University of Michigan Miscellaneous Zoological Occasional Papers No. 85.

GABRIELSON, I.N., and LINCOLN, F.C. 1959. The birds of Alaska. Harrisburg, Pennsylvania: Stackpole Co. and Washington, D.C.: Wildlife Management Institute. 922 p.

GERRARD, J.M., GERRARD, P.N., BORTOLOTTI, G.R., and WHITFIELD, D.W.A. 1983. A 14-year study of bald eagle reproduction on Besnard Lake, Saskatchewan. In: Bird, D.M., ed. Biology and management of bald eagles and ospreys. Ste. Anne de Bellevue, Quebec: Harpell Press. 47-57.

GERRARD, J.M., WHITFIELD, D.W.A., GERRARD, P., GERRARD, P.N., and MAHER, W.J. 1978. Migratory movements and plumage of subadult Saskatchewan bald eagles. Canadian Field-Naturalist 92:375-382.

GRIER, J.W. 1982. Ban of DDT and subsequent recovery of reproduction in bald eagles. Science 218:1232-1235.

HANSEN, A.J., and HODGES, J.I. 1985. High rates of nonbreeding adult bald eagles in southeastern Alaska. Journal of Wildlife Management 49:454-458.

HAUGH, J.R., and HALPERIN, K.C. 1976. Evaluation of raptor populations: Portage Glacier area, Denali Highway area, Yukon River pipeline crossing area, and Yukon River and Porcupine River tributaries. Unpubl. report. Anchorage, Alaska: Bureau of Land Management. 58 p. Available at the U.S. Fish and Wildlife Service Library, 1011 E. Tudor Road, Anchorage, Alaska 99503, U.S.A.

HEHNKE, M.F. 1973. Nesting ecology and feeding behavior of bald eagles on the Alaska Peninsula. M.S. thesis. Humboldt State University, Arcata, California. 56 p.

HINCKLEY, F.C. 1900. Notes on the animal and vegetable life of the region of the Susitna and Kuskokwim Rivers. In: Spurr, J.E., ed. A reconnaissance in southeastern Alaska in 1989. U.S. Geological Survey Annual Report 20, Part VII, 1889-1899:76-85.
KESSEL, B., and GIBSON, D. 1978. Status and distribution of Alaska birds. Studies in Avian Biology 1:1-110.

KESSEL, B., MACDONALD, S.O., GIBSON, D.D., COOPER, B.A., and ANDERSON, B.A. 1982. Susitna Hydro Project Environmental Studies Phase I. Annual report on birds and nongame mammals. Unpubl. report to Alaska Power Authority. Available at the Elmer E. Rasmuson Library, University of Alaska Fairbanks, P.O. Box 756808, Fairbanks, Alaska 99775, U.S.A.

KUROPAT, P. 1986. Beaver Creek raptor survey 1986. Unpubl. report. Fairbanks, Alaska: Bureau of Land Management. Available at the U.S. Fish and Wildlife Service Library, 1011 E. Tudor Road, Anchorage, Alaska 99503, U.S.A.

LAING, H.M., and TAVERNER, P.A. 1929. Notes on birds collected and observed in Chitina River region, Alaska. Annual report. National Museum of Canada Bulletin 56:72-95.

LEIGHTON, F.A., GERRARD, J.M., GERRARD, P., WHITFIELD, D.W.A., and MAHER, W.J. 1979. An aerial census of bald eagles in Saskatchewan. Journal of Wildlife Management 43:61-69.

MINDELL, D.P. 1983. Nesting raptors in southwestern Alaska: Status, distribution, and aspects of biology. Alaska Technical Report 8. Anchorage: Bureau of Land Management. 59 p.

MINDELL, D.P., and CRAIGHEAD, F.L. 1981. Peregrine falcon status and prey, and observations of other raptors on the middle and lower Yukon River, Alaska, 1982. Unpubl. report. Anchorage, Alaska: U.S. Fish and Wildlife Service. 34 p. Available at the U.S. Fish and Wildlife Service Library, 1011 E. Tudor Road, Anchorage, Alaska 99503, U.S.A.

MURIE, O.J. 1921-22. Unpubl. field notes. Available at the Alaska Polar Regions Department, Elmer E. Rasmuson Library, University of Alaska Fairbanks, P.O. Box 756808, Fairbanks, Alaska 99775, U.S.A.

OSGOOD, W.H., and BISHOP, L.B. 1900. Results of a biological reconnaissance of the Yukon River region. North American Fauna No. 19.Washington, D.C.: U.S. Fish and Wildlife Service.

PARKER, J. 1988. Susitna Valley bald eagle survey. Unpubl. report. Anchorage, Alaska: U.S. Fish and Wildlife Service. 8 p. Available at the U.S. Fish and Wildlife Service Library, 1011 E. Tudor Road, Anchorage, Alaska 99503, U.S.A.

RITCHIE, R.J. 1982. Investigations of bald eagles, Tanana River, Alaska, 1977-80. In: Ladd, W., and Schempf, P.F., eds. Proceedings of Symposium and Workshop in Raptor Management and Biology in Alaska and Western Canada. Anchorage, Alaska: U.S. Fish and Wildlife Service. 55-67.

. 1984. Results of raptor surveys along the Porcupine River and Salmon Fork of the Black River, Alaska, 1984. Unpubl. report. Anchorage, Alaska: U.S. Fish and Wildlife Service. 17 p. Available at the U.S. Fish and Wildlife Service Library, 1011 E. Tudor Road, Anchorage, Alaska 99503, U.S.A.

RITCHIE, R.J., and AMBROSE, R.E. 1976. An investigation of peregrine falcon activity and habitat for cliff-nesting raptors in the Kuskokwim River, McGrath to Aniak. Unpubl. report. Anchorage, Alaska: U.S. Fish and Wildlife Service. 32 p. Available at the U.S. Fish and Wildlife Service Library, 1011 E. Tudor Road, Anchorage, Alaska 99503, U.S.A. 
RITCHIE, R.J., and AMBROSE, R.E. 1987. Winter records of bald eagles, Haliaeetus leucocephalus, in interior Alaska. Canadian Field-Naturalist 101:86-87.

ROBARDS, F.C., and KING, J.G. 1966. Nesting and productivity of bald eagles, Southeast Alaska. Unpubl. report. Anchorage, Alaska: U.S. Fish and Wildlife Service. 14 p. + maps. Available at the U.S. Fish and Wildlife Service Library, 1011 E. Tudor Road, Anchorage, Alaska 99503, U.S.A.

ROSENEAU, D.G. 1974. A continuation of studies of raptorial bird nesting sites along proposed pipeline routes in Alaska. Unpubl. report. Calgary, Alberta: Canadian Arctic Gas Ltd. 69 p. Available at the U.S. Fish and Wildlife Service Library, 1011 E. Tudor Road, Anchorage, Alaska 99503, U.S.A.

ROSENEAU, D., and BENTE, P. 1979. A raptor survey of the proposed Northwest Alaska Pipeline Company Gas Pipeline route: The U.S.-Canada Border to Prudhoe Bay, Alaska. Unpubl. report. Prepared by LGL Ecological Resource Associates, Inc., Fairbanks, Alaska for Fluor Northwest, Inc. 82 p. Available at the Elmer E. Rasmuson Library, University of Alaska Fairbanks, P.O. Box 756808, Fairbanks, Alaska 99775, U.S.A.

SCHEMPF, P. 1989. Raptors in Alaska. In: Pendleton, B.G., ed. Proceedings of the Western Raptor Management Symposium and Workshop. National Wildlife Federation Science and Technology Series No. 12. 144-154.

SHERROD, S.K., WHITE, C.M., and WILLIAMSON, F.S.L. 1976. Biology of the bald eagle on Amchitka Island, Alaska. Living Bird 15:143-182.

SPRINGER, A.M., ROSENEAU, D.G., and BENTE, P.J. 1979. Numbers and status of peregrine falcons on the Colville River, middle Yukon River and lower Yukon River, Alaska, 1979. Unpubl. report. Anchorage, Alaska: U.S. Fish and Wildlife Service. 69 p. Available at the U.S. Fish and Wildlife Service Library, 1011 E. Tudor Road, Anchorage, Alaska 99503, U.S.A.

STALMASTER, M.V. 1987. The bald eagle. New York: Universe Books. 227 p.
SWENSON, J.E. 1983. Is the northern interior bald eagle population in North America increasing? In: Bird, D.M., Seymour, N.R., and Gerrard, J.M., eds. Biology and management of bald eagles and ospreys. Ste. Anne de Bellevue, Quebec: MacDonald Raptor Research Centre, McGill University and Raptor Research Foundation, Inc. 23-34.

TIMM, K.T., DOYLE, T.J., and BREESER, S.W. 1993. Raptor baseline inventory in the upper Tanana valley, Alaska, 19611993. Unpubl. report. Tetlin, Alaska: U.S. Fish and Wildlife Service. 27 p. Available at the U.S. Fish and Wildlife Service Library, 1011 E. Tudor Road, Anchorage, Alaska 99503, U.S.A.

WAHRHAFTIG, C. 1965. Physiographic divisions of Alaska. U.S. Geological Survey Professional Paper No. 482. 52 p.

WHITE, C.M. 1974. Survey of the peregrine falcon and other raptors in the proposed Susitna River Reservoir impoundment areas. Unpubl. report. Anchorage: Alaska: U. S. Fish and Wildlife Service. 4 p. Available at the U.S. Fish and Wildlife Service Library, 1011 E. Tudor Road, Anchorage, Alaska 99503, U.S.A.

WHITE, C.M., and BOYCE, S. 1978. A profile of various rivers and their raptor populations in western Alaska, 1977. Anchorage, Alaska: Bureau of Land Management. Technical Report 1:1-77.

WHITE, C.M., and CADE, T.J. 1975. Raptor studies along the proposed Susitna powerline corridors, oil pipelines and in the Yukon and Colville River regions of Alaska. Unpubl. report. Anchorage, Alaska: U.S. Fish and Wildlife Service. 28 p. Available at the U.S. Fish and Wildlife Service Library, 1011 E. Tudor Road, Anchorage, Alaska 99503, U.S.A.

WILBOR, S. 1989. An aerial survey for nesting bald eagles along the Copper River, upper Delta River, Tangle Lakes, Paxson Lake, the Gulkana River drainage, and Gulkana Basin lakes, Alaska, 24-27 May 1989. Unpubl. report. Fairbanks, Alaska: U.S. Fish and Wildlife Service. 5 p. Available at the U.S. Fish and Wildlife Service Library, 1011 E. Tudor Road, Anchorage, Alaska 99503, U.S.A. 